\title{
Metatheoretical Issues of the Evolution of the International Political Economy
}

\author{
Aleksy Kwilinski ${ }^{1,2,3, *(1)}$, Nataliya Dalevska ${ }^{3,4}$ and Vyacheslav V. Dementyev ${ }^{5}$ \\ 1 Department of Management, Faculty of Applied Sciences, WSB University, 41-300 Dabrowa Gornicza, Poland \\ 2 The London Academy of Science and Business, 3rd Floor, 120, Baker Street, London W1U 6TU, UK \\ 3 Institute for International Cooperation Development, 24-26/1, Kazimierza Wielkiego Street, \\ 61-863 Poznań, Poland; dalevskanm@gmail.com \\ 4 Department of Economics of Enterprise, Faculty of Economics and Management, Donetsk National Technical \\ University, 2, Shybankova Square, 85300 Pokrovsk, Donetsk Region, Ukraine \\ 5 Vyacheslav V. Dementyev Department of Economic Theory, Financial University under the Government of \\ the Russian Federation, 49 Leningradsky Prospekt, 125993 Moscow, Russia; dementyevv@mail.ru \\ * Correspondence: a.kwilinski@london-asb.co.uk or akwilinski@wsb.edu.pl
}

Citation: Kwilinski, Aleksy, Nataliya Dalevska, and Vyacheslav V. Dementyev. 2022. Metatheoretical Issues of the Evolution of the International Political Economy. Journal of Risk and Financial Management 15: 124. https:// doi.org/10.3390/jrfm15030124

Academic Editor: Thanasis Stengos

Received: 31 December 2021

Accepted: 28 February 2022

Published: 5 March 2022

Publisher's Note: MDPI stays neutral with regard to jurisdictional claims in published maps and institutional affiliations.

Copyright: (C) 2022 by the authors. Licensee MDPI, Basel, Switzerland. This article is an open access article distributed under the terms and conditions of the Creative Commons Attribution (CC BY) license (https:// creativecommons.org/licenses/by/ $4.0 /)$.

\begin{abstract}
The topicality of the international political economy is determined by the complexity and dynamism of transformation processes in the world economic system, which are developing through information networks and financial technologies. The purpose of the article is to reveal the meta-theory elements of the international political economy in the context of their renewal in the context of the world economic system development in the wave of "information society". To obtain scientifically sound results, the article uses the historical-logical method, the dialectical method of proceeding from the abstract to the concrete, institutional and evolutionary approaches. The article develops theoretical and methodological foundations for developing the international political economy. It is substantiated that the research agenda of the international political economy is characterized by socio-integrative trends of economic development in the global dimension. The interaction among actors of international relations is analyzed, and the structural components of their functional transformation under the conditions of integration processes advance within the world political and economic space are determined. It is concluded that the international political economy serves as a theoretical foundation, an integral general theoretical basis for establishing adaptive conceptual frameworks for building trust and solidarity among the subjects of the world economic system. Theoretical and methodological principles of the international political economy should be based on analyzing systemic and structural transformations of the world economic system; determining the criteria of social legitimacy of international authorities, based on the norms and values of social and environmental justice; and developing conditions for fulfilling the individual's creative potential the field of world social capital.
\end{abstract}

Keywords: international political economy; world economic system; international relations; world political and economic space; actors of international relations; economic development; socialization; institutionalization; legitimation

\section{Introduction}

The world economic system development in the wave of "information society" (Masuda 1983) is characterized by the multifaceted and complex nature of transformation processes, which are accompanied by a wide range of crisis phenomena. The instability of the world economic system makes it urgent to study and forecast possible options for its development, directions, and forms of transforming the system of international relations, political and economic institutions within the world political and economic space. This will be possible by building such theoretical models that would lay the groundwork for further transformations in the world economic system. 
Analyzing the origins of global crises, scientists raised questions about metatheoretical provisions that update the research agenda of the international political economy, which can create the prerequisites for economic growth based on using the potential benefits of an open economy.

As Beck (2005) maintains, the international political economy is gaining relevance and scientific significance due to the fact that, on the one hand, it unfolds as a theory of power over the strategic space of the transnational economy, and on the other hand, it picks up a resulting counter-question: how is it possible to prepare a policy based on the idea of statehood (in its basic concepts, strategic power space, institutional typical conditions) to respond not only to the challenges of the world economy, but also to the global problems arising from modernization?

According to Gilpin (1987), the subject of the international political economy is related to three fundamental issues. First, it is a question about the causes and consequences of the emergence of a global market economy: does the functioning of the global market follow its own internal logic, or does it depend on government regulators? Secondly, it is a question about the dialectic of economic and political change: To what extent can economic instability cause political turmoil? How do states' aspirations to preserve their sovereignty and globalization of economic regulation relate? Third, it is a question of political ways for states to enter the process of globalization: what means does the state have to control the market and what strategies does the global market have at its disposal—or rather, the forces that represent it-to overcome or circumvent state restrictions?

Morgenthau (1948) argues that the societal preconditions of the international political economy were formed during the growing interdependence of the world, the increasing role of transnational corporations, firms, enterprises, and banks, and the exacerbation of problems related to access to natural resources and their commercialization. The identification and analysis of the ways and means of economic and political influence on international relations and the world order necessitated the inventory and revision of its theoretical arsenal and, consequently, the abandonment of the realist paradigm provisions, according to which "a key category of political realism is the concept of interest defined in terms of power. It is this concept that determines the specificity of the political sphere, its difference from other spheres of life ..." Without the concept of interest, it is impossible to separate political phenomena from non-political ones and bring at least some order to the political environment.

As Savchuk (2011) asserts, the emergence of the international political economy is associated with the specifics of real processes in the system of international economic relations in the second half of the XX to the early XXI century, particularly with the transition of these relations to a qualitatively new status, which requires further development of the institutional field of the subject of the modern political economy. The research object of the international political economy is the modern globalized economy, and the subject involves political, economic, social institutions and specific institutional forms that define and regulate the essence, nature, field, direction, and effectiveness of relations among major subjects of international economic life. Defining the object and subject of the international political economy also means outlining the basic laws and development patterns of globalization in all spheres of the economic and social lives of the world economic system, because without identifying these patterns, it is almost impossible to form either a conceptual vision of the internal causes and levers of globalization or a theoretical forecasting model that would allow pursuing a balanced, realistic economic policy to reconcile and implement national, regional, supranational economic, social and other forms of interest in their dynamics. The institutional field of the subject of the international political economy is formed, first of all, under the influence of modern views on the essence and functions of the political economy in general.

Strange (1988) emphasizes that the rapidity of events in the international economy and the changes associated with economic interdependence raise new questions about the nature of the national interest. A consistent step in this direction is the study of international 
economic relations on the basis of political priority. The main issue of the international political economy - the question about the relationship between the state and the marketis determined by the structural understanding of power. Power is like a quadrilateral, the sides of which are the structures of production, security, knowledge, and finance. Each side is closely interconnected with the other three, which in turn affects the relationship between "power" and "market".

As Tarasevych (2012) notes, remaining a science about the wealth, political economy in a broad sense is evolving in the direction of expanding and complicating its range of problems. In response to new objective realities, its dominant paradigms, subject components (directions, levels, sectors), methods, and names are changing. The recognition of political economy in a broad sense actualizes the set of problems covered by the political economy in a narrow sense. Thus, the "global (international) political economy", which is actively developing, can be described as a special field and/or direction of political economy in a broad sense.

Filipenko (2012) indicates that the need to develop a political-economic concept of the modern world economy is due to the growth of its scale, especially the financial sector, structure diversification of the world economy, the complexity of transformation processes, and more. As one of the structural units of general scientific methodology, the international political economy is based first of all on the world-system approach. Secondly, the international political economy has been significantly influenced by various theories of hegemonic stability, the essence of which is the existence of a hegemonic leader (or group of leaders) who supports the liberal world order. Third, the international political economy pays great attention to the functioning of "international regimes"-systems of institutions at the global level. These include studies of the economic preconditions of conflicts, problems of international economic cooperation, and global governance.

Despite the scientific value of elaborating the methodological problems of world economic system evolution (Amin 1996; Cotula 2012; Cyfert et al. 2021; Dalevska et al. 2019; Dossani and Kenney 2007; Dasgupta et al. 2021; De Bièvre and van Ommeren 2021; Dzwigol 2021; Galiani et al. 2019; Garrett 2006; Geels 2005; Elbahnasawy and Ellis 2022; Elbe and Long 2020; Fuchs 2007; Gilpin 1987; Graham and Tucker 2019; Graz et al. 2020; Hussain et al. 2020, 2021; Huang 2010; Fossung et al. 2021; Keohane and Nye 1977; Kharazishvili et al. 2020, 2021a, 2021b; Kravchenko 2019; Kurowska-Pysz and Szczepańska-Woszczyna 2017; Kuzior et al. 2020; Las Heras 2018; Levitt 1983; Marlin-Bennett and Johnson 2021; Medeiros 2021; McNally 2012; Nunn and Shields 2022; Paterson 2021; Postlewaite and Schmeidler 1986; Shkodina et al. 2020; Simmons and Zachary 2004; Smith and White 1992; Smirnova et al. 2021; Stiglitz 2002; Tanaka 2021; Tsoukas 1997; van Ommeren et al. 2021; Wallerstein 1995), the issues of the dialectical interrelation between global productive forces and international relations, principles of general civilizational transformations at the present stage of the world economic system development remain insufficiently substantiated.

The purpose of this article is to reveal the metatheory elements of the international political economy in the context of their renewal under the condition of the world economic system development in the wave of "information society".

\section{Materials and Methods}

This research is informed by the works of scholars in the field of the international economics and international relations (Arrighi 2007; Berger and Luckmann 1966; Castells 2010; Filipenko 2012; Fukuyama 2002; Huntington 1993; Hrytsenko 2015, 2018; Keohane and Nye 1977; Parsons 1971; Porter 1998; Ringquist 2003; Robertson 1992; Rosenau 2006; Ruggie 1982; Sabadash and Denysenko 2018; Savchuk 2011; Tarasevych 2012; Wallerstein and Clesse 2003), sociology (Gadzhiev 2012; Golovakha and Panina 2001; Hegel 2018; Toffler 1980), philosophy of systems (Chebotarov 2003; Laszlo 1991; Laszlo and Krippner 1998) and the materials of authors' research (Dalevska 2013, 2014, 2017; Dementyev et al. 2021a, 2021b; Dementyev and Kwilinski 2020; Kwilinski et al. 2019, 2020). To reveal the metatheory elements of the international political economy, there are applied the historical- 
logical method of research and the dialectical method of proceeding from the abstract to the concrete, which includes general scientific methods of analysis and synthesis, induction and deduction, etc. Substantiation of socio-integrative tendencies of economic development in the global dimension and directions of functional transformation of actors of international relations is carried out on the basis of institutional and evolutionary approaches.

\section{Results}

The development of the productive forces of the world economic system permeates all human activity, in its deepest essence. Modern features of this process are the vertical and horizontal integration of actors of international relations within the world political and economic space, the growing role of venture entrepreneurship, communication technologies, networking, strengthening control over world resources through the use of financial mechanisms, and more. At the same time, modern integration processes are multidimensional in nature, necessitating the transformation of international relations as a substantial basis for the world economic system evolution. At the heart of this transformation, there lies the contradiction between the integration processes within the global political and economic space, developing through information network and financial technologies, and the localization of material and labor resources that cannot move in space at the speed of information and financial flows, which has various forms of manifestation and solution (Hrytsenko 2015, 2018).

Thus, contradictory integration processes within the world political-economic space give rise to a variety of sources of the international political economy development (Table 1).

Table 1. Theoretical and methodological principles of the international political economy evolution.

\begin{tabular}{|c|c|c|}
\hline $\begin{array}{l}\text { Ontology of the International Political } \\
\text { Economy Evolution }\end{array}$ & The Goal-Setting Concept & Means to Achieve the Goal \\
\hline $\begin{array}{l}\text { Analyzing axiomatic principles in } \\
\text { structuring the world political and } \\
\text { economic space, taking into account the } \\
\text { complexity of the interrelationship } \\
\text { between global productive forces and } \\
\text { international relations }\end{array}$ & $\begin{array}{l}\text { Researching theoretical and } \\
\text { methodological principles of } \\
\text { conceptualization of international } \\
\text { socio-economic relations under the } \\
\text { conditions of hierarchical construction of } \\
\text { world political and economic space }\end{array}$ & $\begin{array}{l}\text { Substantiating conditions and principles } \\
\text { of forming the international strategy of } \\
\text { economic development taking into } \\
\text { account multidimensionality of causal } \\
\text { interactions among subjects of the world } \\
\text { economic system }\end{array}$ \\
\hline $\begin{array}{l}\text { Formulating the concept of functions' } \\
\text { multidimensional rationality and power } \\
\text { influence by actors of international } \\
\text { relations within the world political and } \\
\text { economic space }\end{array}$ & $\begin{array}{l}\text { Developing the criteria for } \\
\text { socio-economic consequences of the } \\
\text { world economic system globalization and } \\
\text { directions of functional transformation of } \\
\text { actors in international relations }\end{array}$ & $\begin{array}{l}\text { Identifying normative and targeted } \\
\text { regulations for coordinating economic, } \\
\text { political, social, and environmental } \\
\text { interests of the world economic system }\end{array}$ \\
\hline $\begin{array}{l}\text { General civilizational transformations of } \\
\text { the scientific worldview methodology of } \\
\text { the legitimacy of a multilateral global } \\
\text { economic order }\end{array}$ & $\begin{array}{l}\text { Researching the cognitive dimension of } \\
\text { international codes of conduct by the } \\
\text { subjects of the world economic system } \\
\text { and social standards of rationalizing the } \\
\text { struggle for power on the global arena }\end{array}$ & $\begin{array}{l}\text { Identifying transformational changes in } \\
\text { the institutional structure of the world } \\
\text { political and economic space, developing } \\
\text { criteria for social legitimacy of } \\
\text { international power structures }\end{array}$ \\
\hline $\begin{array}{l}\text { The impact of power relations on the state } \\
\text { and development of the world power } \\
\text { institutions' legitimacy and the growing } \\
\text { interconnectedness and interdependence } \\
\text { of national systems in the world economy }\end{array}$ & $\begin{array}{l}\text { Analyzing the reproduction of political } \\
\text { and economic inequalities of actors in } \\
\text { international relations, defining } \\
\text { opportunities for using resources of } \\
\text { world human development on the basis } \\
\text { of the values of humanism }\end{array}$ & $\begin{array}{l}\text { Substantiating the relationship between } \\
\text { national economic interests, national } \\
\text { needs, and institutional principles of the } \\
\text { world economic system development }\end{array}$ \\
\hline $\begin{array}{l}\text { Analyzing ontological bases of legitimate } \\
\text { communication among actors in } \\
\text { international relations under conditions } \\
\text { of development of integration processes } \\
\text { in the world economic system }\end{array}$ & $\begin{array}{l}\text { Studying the features of identifying } \\
\text { adaptive norms of introducing power } \\
\text { within the frameworks of the world } \\
\text { political and economic space }\end{array}$ & $\begin{array}{l}\text { Determining the parameters of a } \\
\text { balanced cycle of structural elements of } \\
\text { the world economy as a multipolar } \\
\text { system in the wave of "information } \\
\text { society" }\end{array}$ \\
\hline
\end{tabular}


Table 1. Cont.

\begin{tabular}{ccc}
\hline $\begin{array}{c}\text { Ontology of the International Political } \\
\text { Economy Evolution }\end{array}$ & The Goal-Setting Concept & Means to Achieve the Goal \\
\hline $\begin{array}{l}\text { The latest trends in reproducing social } \\
\text { capital within the world political and } \\
\text { economic space }\end{array}$ & $\begin{array}{c}\text { Considering the specifics of } \\
\text { communication and information } \\
\text { properties of the world social capital }\end{array}$ & $\begin{array}{c}\text { Developing conditions for fulfilling the } \\
\text { individual's creative potential in the field } \\
\text { of the world social capital }\end{array}$ \\
\hline
\end{tabular}

In the late XX to the early XXI century, there occurred structural transformations in international relations, which have dramatically affected changes in the security environment of the modern international system. In the process of expanding the scale of integration interactions of actors in international relations, the world has faced more complex risks that are not of a tactical but of a systemic nature.

In particular, economic activity should be associated with a sharp global deterioration of the environmental situation in the world, which ultimately turns against a man himself, his health, and his life. Accordingly, economic and environmental contradictions acquire signs of a systemic crisis of modern civilization. The main economic contradiction underlying the "environmental conflict" (Sabadash and Denysenko 2018) is the strengthening of control over natural resources through the use of financial mechanisms. The global struggle for expensive natural resources (land, minerals, clean air, etc.) is carried on by means of a cheap financial and economic resource-money-which deepens economic and environmental collisions, provoking new conflicts.

In this regard, balanced (sustainable) development should be understood as a strategic goal and the global strategy of mankind, which requires the transition from economic growth, which is determined by quantitative indicators, to qualitative economic development on the basis of justice, compatible with renewable (regenerative) and assimilative capabilities of the global life support system.

At the same time, ensuring environmental justice depends to a large extent on finding out the causes of environmental injustice. Thus, E. Ringquist (2003) provides five explanations for why dangerous objects are much more often located in the habitats of certain segments of the population, causing unequal distribution of environmental risk, or environmental injustice. These include the following:

1. Scientific expediency of the location of the object;

2. Market or economic feasibility (low land prices, availability of cheap labor, access to

transport infrastructure and raw materials, etc.);

3. Population mobility;

4. Political power;

5. Targeted discrimination.

However, according to Ringquist (2003), the scientific, technical, and economic feasibility of the objects' location does not in itself justify the occurrence of environmental injustice. Population mobility only partially explains the emergence of this phenomenon, as the middle class tends to leave places where dangerous objects are located, as a result of which land and housing become more accessible to the poorer sections of the population. However, the most important factor is political power. Given the political expediency, companies try to locate dangerous objects in places where they hope for less political resistance. So, the direct participation of actors in international relations in the political process, especially at the international level, is a prerequisite for achieving social and environmental justice.

In fact, the social difficulties of modern civilization evolution caused by the state of social production, the problems of providing a growing population with natural resources are important factors that affect the scale, intensity, and nature of integration processes in the world economic system, exacerbating the systemic nature of crises, "environmental conflicts" in particular. To overcome the impact of these and other factors, it is necessary to optimize the integrity of the world economic system, i.e., to ensure such a state in which there must exist the most effective and stable links among the structural elements that 
make it up. Under these conditions, the growing interest in international political economy justifies the search for qualitatively updated motivations for human activity. In particular, it is necessary to develop an appropriate strategy with tactical mechanisms that is aimed at the following:

1. Creating favorable preconditions for the influence of social factors on global economic development;

2. Strengthening the key functional components of international socio-economic security on the basis of networks of global social capital, socio-economic levers of international regulation of people's labor rights and social guarantees.

This determines the emergence of a number of methodological issues in the international political economy evolution, especially on the prospects of people's social development under conditions of global competition, recognizing the complexity of structural differences in social opportunities and shaping the directions of functional transformation of actors in international relations in the world political and economic space.

In the scientific literature (Arrighi 2007; Wallerstein 1995), the essence of the functional transformation of actors in international relations is related to the idea of distributing power and economic resources, their social reproduction from the standpoint of geopolitical, geoeconomic, institutional features. Accordingly, the variability of the directions of functional transformation of actors in international relations is associated with the process of forming a certain balance of interests of actors in international relations.

Of course, any interaction of actors in international relations is determined by the goal. If the goals of the actors in international relations coincide, there appears a need for integrative motivation. If the goals of the actors in international relations are opposite, there is formed a conflict situation, which can be resolved either through compromise or through the interaction of the type of pressure-subjugation. Finally, the level of competitiveness and proneness to the conflict of actors in international relations can either contribute to or hinder the formation of social solidarity concerning the norms of international order. Under these conditions, the development of a strategy for balancing the interests of actors in international relations should proceed from the following potential starting points:

1. Identification of key factors influencing the functional transformation of actors in international relations;

2. Analysis of socio-economic consequences of these factors' influence and substantiation of the directions of functional transformation of actors in international relations within the framework of the world political and economic space on the basis of social partnership (Table 2).

Thus, we note that the diversity of actors in international relations is the impetus for the centrifugal forces of self-regulatory mechanisms of the world economic system and depends on the specifics of the world political and economic space, the degree of its heterogeneity. At the same time, the main centripetal force is the integrity of nation states in the world political and economic space. This means that the balance of interests of actors in international relations is determined by the level of development of centrifugal and centripetal forces, taking into account the specific features of the processes of socialization, institutionalization, and legitimation within the world political and economic space.

Socialization involves the inculcation of new political institutions in society through studying new norms and values. In the methodological context, the logic of socialization and the logic of social progress are uniordinal in their content. According to G. Hegel (2018), "it is not the state that determines the moral world of the individual, but the moral world of individuals, the spirit of their beliefs and their conscience determine the formation of the state... From this point of view, government institutions and laws fail when confronted with the conscience of individuals, whose spirit differs from these laws and does not authorize them". Highlighting this problem, Galchynskyi (2011) draws attention to implementing in the system of the economic process not only the traditional results of human reproductive labor, but also the full range of values of his creative, innovative in its content, activity. The 
talk is about the three-level purpose of the latter, its implementation as processes of the following:

1. The nature personification;

2. The society construction;

3. Personal wealth formation.

Table 2. Structural components of the functional transformation of actors in international relations within the global political and economic space.

\begin{tabular}{|c|c|c|}
\hline $\begin{array}{l}\text { Factors Influencing the Functional } \\
\text { Transformation of Actors in } \\
\text { International Relations }\end{array}$ & $\begin{array}{l}\text { Socio-Economic Consequences of the } \\
\text { Influence of Factors on the Functional } \\
\text { Transformation of Actors in } \\
\text { International Relations }\end{array}$ & $\begin{array}{l}\text { Directions of Functional } \\
\text { Transformation of Actors in } \\
\text { International Relations }\end{array}$ \\
\hline $\begin{array}{l}\text { Strengthening the interdependence of } \\
\text { actors in international relations and their } \\
\text { interconnectedness in terms of } \\
\text { concentration of banking and financial } \\
\text { capital }\end{array}$ & $\begin{array}{l}\text { Changes in the dominant form of the } \\
\text { organizational structure of enterprises } \\
\text { and inter-firm cooperation, the use of } \\
\text { debt financing of public expenditures }\end{array}$ & $\begin{array}{l}\text { Distribution of government debt, current } \\
\text { transactions account deficits, and } \\
\text { government budget deficits within the } \\
\text { global political and economic space }\end{array}$ \\
\hline $\begin{array}{l}\text { Uneven distribution of benefits of the } \\
\text { international division of labor, change in } \\
\text { property-government relations, } \\
\text { transformation of the international order }\end{array}$ & $\begin{array}{l}\text { Disproportionate development of the } \\
\text { world economy, uneven technological } \\
\text { development, income polarization, } \\
\text { increasing crisis phenomena }\end{array}$ & $\begin{array}{l}\text { The predominant development of the } \\
\text { "tertiary" sector of the economy-the } \\
\text { provision of services, the creation of an } \\
\text { integrated system of international, } \\
\text { national and regional security }\end{array}$ \\
\hline $\begin{array}{l}\text { Increasing the openness of national } \\
\text { economies, internationalization of capital } \\
\text { flows, intensification of global } \\
\text { transactions, communications and risks }\end{array}$ & $\begin{array}{l}\text { Development of interstate cooperation in } \\
\text { economic, political and social spheres, } \\
\text { creation of mechanisms for coordination } \\
\text { of fiscal policy in interstate cooperation } \\
\text { on the basis of integration partnership }\end{array}$ & $\begin{array}{l}\text { Improving the system of institutional } \\
\text { support for economic development on a } \\
\text { global scale, the partnership of } \\
\text { institutions of government, business, and } \\
\text { households, the ability of states to control } \\
\text { the state of the environment }\end{array}$ \\
\hline $\begin{array}{l}\text { Large-scale migration processes, global } \\
\text { social stratification, changes in the } \\
\text { value-normative structure of society }\end{array}$ & $\begin{array}{l}\text { The growth of the number of one-person } \\
\text { households, the accumulation of social } \\
\text { contradictions }\end{array}$ & $\begin{array}{l}\text { Changes in the direction of capital } \\
\text { movements within the world political } \\
\text { and economic space, to maintain an } \\
\text { optimal balance between national and } \\
\text { international interests }\end{array}$ \\
\hline $\begin{array}{l}\text { Transforming knowledge as a producer } \\
\text { of relevant information into a decisive } \\
\text { factor in global economic growth and a } \\
\text { source of global community wealth }\end{array}$ & $\begin{array}{l}\text { The global confrontation between } \\
\text { hierarchical and network structures, } \\
\text { strengthening of regional and local } \\
\text { subjectness, socio-economic convergence } \\
\text { of countries and regions within the } \\
\text { political and economic space }\end{array}$ & $\begin{array}{l}\text { Expansion of information and } \\
\text { communication processes in the world } \\
\text { political and economic space, } \\
\text { cross-border and transnational } \\
\text { cooperation, international production } \\
\text { cooperation }\end{array}$ \\
\hline
\end{tabular}

However, the integrity of the modern organizational type of the world economic system is determined not so much by the unity of physical space, as by the possibility of synchronous global monitoring of economic and social events in real time, the ability of supranational institutions to the operational multilevel projection of global management decisions. Modern society has approached the stage of its development, when the necessary, optimal, and moreover, the only possible, way of its further progress is not the existence and development of some of its spheres and parts at the expense of others, but a common, combined, mutual development of all its elements, spheres, parts. The prosperity and development of all become directly dependent on the well-being and development of each.

The integration of society on the basis of a multidimensional process of social, economic, and political change encourages the expansion of the person's individual freedom, outlining for people choices aimed at ensuring sustainable development and social order in the global dimension. Consequently, international socio-economic security cannot be the prerogative of a single country or group of countries. Accordingly, international socioeconomic security should be studied as a state of the world economic system based on 
fair, mutually beneficial and mutually acceptable principles, which creates conditions for peaceful coexistence and cooperation of actors in international relations for the benefit of the socio-economic progress of each person and humanity in general.

Under such conditions, the international political economy serves as a theoretical foundation, an integral general theoretical basis for establishing adaptive conceptual frameworks for building trust and solidarity among the subjects of the world economic system. Fundamental to the theoretical development of the international political economy is the awareness of the institutional complementarity of heterogeneous elements of the world economic system, based on strategic calculations of the parameters of global economic equilibrium. In view of this, the ontological status of the international political economy can be defined as a borderline interaction among actors in international relations on the basis of institutionalization.

Institutionalization is defined as the process of forming social institutions when there is an ordering and formalization of social ties. This is the process of forming and consolidating social norms, rules, statuses and roles, bringing them into a system that is able to act toward meeting a certain social need (Gadzhiev 2012). Berger and Luckmann (1966) note that "Institutionalization takes place wherever there is a mutual typification of actions by actors of various kinds. In other words, any such typification is an institution. What should be emphasized here is the reciprocity of institutional typification and the typicality not only of actions, but also of actors in institutions". According to Parsons (1971), social institutions act both as special value-normative complexes that regulate the behavior of the individual, and as stable configurations, setting the structure of society.

Thus, institutionalization should be defined as the process of forming new social institutions in three aspects:

1. The process of forming and adopting new social rules by society;

2. Creating organizational structures that are responsible for the articulation and procedure for compliance with these rules and constitute the social infrastructure of institutionalized behavior;

3. Shaping the subjects' attitude to social rules and organizational structures, which reflects the consent of people to this institutional order (Golovakha and Panina 2001).

In terms of this definition, deinstitutionalization is a process of destructing institutional entities and is manifested in the rejection of institutional requirements for social behavior.

Since the structure of the world economic system is a set of internally necessary and stable links among its elements within the essential whole, the elements and structure of the world economic system mutually determine each other. The set of connections among the elements of the world economic system is determined by their properties, qualitative characteristics. However, the properties and qualitative characteristics of the elements of the world economic system depend on its structure. Thus, the change of elements of the world economic system leads to the transformation of its structure. At the same time, new social institutions are being formed, and regressive institutional structures are being destroyed.

The effectiveness of any international institution, as well as the system of international relations in general, is determined by the extent to which it complies with the interests of the subjects whose actions it regulates. The advantages over certain institutions depend on the ratio of benefits and costs that each of these entities receives and incurs in the operation of these institutions, as well as on the costs of their reform. The benefits and costs of existing international institutions may be unevenly distributed among participants in international relations. As a result, a new conflict of interest may arise between them-over the content of certain institutions.

In particular, the question of the institutions' effectiveness is largely determined by the interests of subjects politically dominant in international relations, whose interests are decisive in the current institutional structure of the world political and economic space. Even if the functioning of certain international institutions undermines the well-being of certain participants in international relations but at the same time leads to the redistribution 
of benefits in favor of certain dominant actors in these relations, these institutions will be preserved and maintained. Due to the high transaction costs, participants in international relations who lose from functioning institutions may be unable to initiate the process of reforming them, during which they will have to receive consent to change existing institutions from stakeholders interested in their preservation (for example, by additional redistribution of resources). In such a situation, it is likely that the losing actors may "adjust" their interests to the interests of politically dominant actors, which may lead to a change in the balance of power in international relations and to a modification of the institutional environment.

Thus, the emergence of the structure of the world economic system with new qualitative characteristics cannot but cause the coexistence of processes of institutionalization and deinstitutionalization. The availability of the determining structural element of the world economic system and the connections among its structural elements determine the genesis of structural transformations, as well as their functional orientation. Accordingly, the qualitative definition of the elements of the world economic system changes, and the connections among them and new functional interdependencies of the subjects of the world economic system appear.

Naturally, changes and transformations unfold both in space and in time. The links among the structural elements of the world economic system, the level of their stability, and the functional orientation of transformation processes determine the probability of both ascending and descending-progressive or regressive-changes in the course of structural transformations. However, the dynamism of structural transformations determines the gradual development of the world economic system. In particular, in the first stage, the transformation processes that are accompanied by a change (increase or decrease) in the number of elements of the world economic system and the properties of the links among them do not cause its qualitative changes. Extremely important in this case is the nature and strength of the influence of the institutional environment on the course of changes within the structure and, ultimately, on the threshold of its stability.

According to the philosophy of the complex dynamic systems development (Chebotarov 2003; Laszlo 1991; Laszlo and Krippner 1998), the accumulation of change, which approaches the stability limit of the structure but does not exceed it, leads to a state of an unstable equilibrium. Under the condition of their further accumulation, the threshold of the structure's stability is destroyed, which means the transition to the second stage of structural transformations. There appear two kinds of changes: the old structure is destroyed and a new one is constituted. Structural transformations are accompanied by the emergence of antagonism of contradictions, which, under the conditions of such duality-namely, the interdependence of the old that is ruined and the new that emerges-have a different vector, strength, and rate of growth. In the second stage, the structural elements of the formed system acquire qualitative certainty with the corresponding system of connections among them. The transformation of the old structure into a new one, thus, covers all the properties of the system as such and therefore has a systemic nature.

However, the reproduction of systematicity contributes to the hierarchy of contradictions determined by the qualitative parameters of the structure of the world economic system. In turn, the consolidation of the hierarchy of contradictions determines the transition to the third stage of structural transformations, namely, to stable evolutionary variability.

Finally, the manageability level of the world economic system depends on the nature, number, and hierarchy of governance entities, their governance actions, the extent to which governance by elements of the system is adequate to major social challenges and security threats of economic and environmental nature, norms, rules, mechanisms, regimes, and institutions on the basis of the legitimation process. Thanks to legitimation, the results of socialization and institutionalization are compared with the civilizational values of the world economic system. Under such conditions, legitimacy is of "through" importance both in relation to institutions and in the directions of exercising power. Within it, the search for common elements in different approaches to solving world economic, political and 
social problems takes into account the systemic interdependence of actors in international relations.

Summing up, it stands to mention that the theoretical and methodological foundations of modern international political economy should be based on the following:

1. Analyzing system-structural transformations of the world economic system;

2. Determining the criteria of social legitimacy of international power structures based on the norms and values of social and environmental justice;

3. Developing conditions for fulfilling of the individual's creative potential in the field of world social capital.

\section{Discussion}

The systemic definition of the subject space of the international political economy in the wave of "information society" is characterized by growing openness, multilevel integrity, and communicative activity of the world economic system. Under these conditions, it seems necessary and timely to study politically and economically the nature of systemic and structural transformations of the world economic system and trends in the relationship between political and economic processes from the standpoint of forming a concept and constructive predictive model of qualitative change direction in the system of international relations in order to ensure sustainable development.

Accordingly, the methodology of the international political economy is shaped under the influence of scientific concepts of economic development in the global dimension: "sustainable development", "world-system analysis" (Wallerstein and Clesse 2003), "dependent development" (Amin 1996), etc. Analyzing the drivers of the current stage of the world economic system evolution on the methodological basis of the international political economy, scientists in their studies substantiate the following:

1. Evolutionary variability of the world economic system through the renewal of structural elements of the world economic system, based on the unity of creation and destruction of ties among actors in international relations (Filipenko 2012; Keohane and Nye 1977; Porter 1998; Rosenau 2006; Stiglitz 2002; Wallerstein and Clesse 2003); 2. Increasing the importance of non-economic (socio-political, socio-cultural) factors in the evolution of the world economic system (Arrighi 2007; Fukuyama 2002; Huntington 1993; Levitt 1983; Tarasevych 2012; Robertson 1992);

3. Shaping a global institutional environment through the coordination of conflicting interests of actors in international relations (Amin 1996; Castells 2010; Ruggie 1982; Savchuk 2011; Toffler 1980).

The conceptualization of these positions confirms the main results obtained in the article. However, current research in the field of finding a response to the global COVID19 crisis is based in particular on new materialist approaches, namely the increasing importance of non-human life processes (White 2015) in the development of the world economic system (Elbe and Long 2020; Marlin-Bennett and Johnson 2021).

\section{Conclusions}

The research agenda of the international political economy in the wave of the "information society" is marked by socio-integrative trends of economic development in the global dimension. Under such conditions, the international political economy serves as a theoretical foundation, an integral general theoretical basis for establishing adaptive conceptual frameworks for building trust and solidarity among the subjects of the world economic system. Fundamental to the theoretical development of the international political economy is the awareness of the institutional complementarity of heterogeneous elements of the world economic system, based on strategic calculations of the parameters of global economic equilibrium. This provides the international political economy with the status of a scientific discipline that combines theoretical fundamental and practical applied directions, particularly in studying the integrative dimension of the international relations transformation as a substantial basis for developing the world economic system. Of particular 
relevance are the orderliness issues of the world economic system, which are manifested through the institutional framework of justice, responsibility, and social partnership of actors in international relations within the world political and economic space. That is why the theoretical and methodological principles of the international political economy should be based on analyzing systemic and structural transformations of the world economic system; determining the criteria of social legitimacy of international authorities, based on the norms and values of social and environmental justice; and developing conditions for fulfilling the individual's creative potential in the field of world social capital.

A promising area for further research is the development of a subordinate system of contradictions inherent in the current stage of the world economic system development, which will provide opportunities for a systematic understanding of the evolution patterns of the world political and economic space.

Author Contributions: Conceptualization, A.K., N.D. and V.V.D.; methodology, A.K., N.D. and V.V.D.; software, A.K., N.D. and V.V.D.; validation, A.K., N.D. and V.V.D.; formal analysis, A.K., N.D. and V.V.D.; investigation, A.K., N.D. and V.V.D.; resources, A.K., N.D. and V.V.D.; data curation, A.K., N.D. and V.V.D.; writing—original draft preparation, A.K., N.D. and V.V.D.; writing-review and editing, A.K., N.D. and V.V.D.; visualization, A.K., N.D. and V.V.D.; supervision, A.K., N.D. and V.V.D.; project administration, A.K., N.D. and V.V.D.; funding acquisition, A.K., N.D. and V.V.D. All authors have read and agreed to the published version of the manuscript.

Funding: This research received no external funding.

Institutional Review Board Statement: Not applicable.

Informed Consent Statement: Not applicable.

Data Availability Statement: Not applicable.

Acknowledgments: The authors are very grateful to the anonymous referees for their helpful comments and constructive suggestions.

Conflicts of Interest: The authors declare no conflict of interest.

\section{References}

Amin, Samir. 1996. The challenge of globalization. Review of International Political Economy 3: 216-59. [CrossRef]

Arrighi, Giovanni. 2007. Adam Smith in Beijing: Lineages of the Twenty-First Century. London: Verso.

Beck, Ulrich. 2005. Power in the Global Age. Cambridge: Polity Press.

Berger, Peter Ludwig, and Thomas Luckmann. 1966. The Social Construction of Reality: A Treatise in the Sociology of Knowledge. New York: Anchor Books.

Castells, Manuel. 2010. The Information Age: Economy, Society and Culture. Volume 1: The Rise of the Network Society, 2nd ed. Oxford: Wiley Blackwell.

Chebotarov, Viacheslav. 2003. The Theory of Structural Transformations as a Philosophical Problem. Philosophical Thought 1: 123-32.

Cotula, Lorenzo. 2012. The international political economy of the global land rush: A critical appraisal of trends, scale, geography and drivers. The Journal of Peasant Studies 39: 649-80. [CrossRef]

Cyfert, Szymon, Anna Chwiłkowska-Kubala, Witold Szumowski, and Radosław Miśkiewicz. 2021. The process of developing dynamic capabilities: The conceptualization attempt and the results of empirical studies. PLoS ONE 16: e0249724. [CrossRef]

Dalevska, Nataliya. 2013. Methodological issues of social order relationships analysis in categorial structures of international political economy. Economic Annals-XXI 11-12: 12-15.

Dalevska, Nataliya. 2014. Directions of Functional Transformation of International Entities within Globalized World Economy. Business Inform 11: 14-18.

Dalevska, Nataliya. 2017. The institutional determinants of global economic development. In Economic Transformation in Ukraine: Comparative Analysis and European Experience. Edited by Piotr Glowski and Oleksii Kvilinskyi. Warsaw: Institute for International Cooperation Development \& Consilium Sp. z o.o., pp. 100-11.

Dalevska, Nataliya, Valentyna Khobta, Aleksy Kwilinski, and Sergey Kravchenko. 2019. A model for estimating social and economic indicators of sustainable development. Entrepreneurship and Sustainability Issues 6: 1839-60. [CrossRef]

Dasgupta, Byasdeb, Archita Ghosh, and Bishakha Ghosh. 2021. Neoliberalism in the Emerging Economy of India. London: Routledge. [CrossRef]

De Bièvre, Dirk, and Emile van Ommeren. 2021. Multilateralism, Bilateralism and Institutional Choice: The Political Economy of Regime Complexes in International Trade Policy. Global Policy 12: 14-24. [CrossRef] 
Dementyev, Vyacheslav V., and Aleksy Kwilinski. 2020. Institutional Component of Production Costs. Journal of Institutional Studies 12: 100-16. [CrossRef]

Dementyev, Vyacheslav, Nataliya Dalevska, and Aleksy Kwilinski. 2021a. Innovation and Information Aspects of the Structural Organization of the World Political and Economic Space. Virtual Economics 4: 54-76. [CrossRef]

Dementyev, Vyacheslav V., Nataliya Dalevska, and Aleksy Kwilinski. 2021b. Institutional Determinants of Structuring the World Political and Economic Space. Paper presented at the 37th International Business Information Management Association, Cordoba, Spain, April 1-2.

Dossani, Rafiq, and Martin Kenney. 2007. The Next Wave of Globalization: Relocating Service Provision to India. World Development 35: 772-91. [CrossRef]

Dzwigol, Henryk. 2021. Meta-Analysis in Management and Quality Sciences. Marketing and Management of Innovations 1: 324-35. [CrossRef]

Elbahnasawy, Nasr G., and Michael A. Ellis. 2022. Inflation and the Structure of Economic and Political Systems. Structural Change and Economic Dynamics 60: 59-74. [CrossRef]

Elbe, Stefan, and Christopher Long. 2020. The political economy of molecules: Vital epistemics, desiring machines and assemblage thinking. Review of International Political Economy 27: 125-45. [CrossRef]

Filipenko, Anton. 2012. Political Economy of the World Economy. Journal of European Economy 11: 4-13.

Fossung, Gerard Atabong, Vasileios Chatzis Vovas, and A. M. M. Shahiduzzaman Quoreshi. 2021. Impact of Geopolitical Risk on the Information Technology, Communication Services and Consumer Staples Sectors of the S\&P 500 Index. Journal of Risk and Financial Management 14: 552. [CrossRef]

Fuchs, Christian. 2007. Internet and Society: Social Theory in the Information Age. New York: Routledge. [CrossRef]

Fukuyama, Francis. 2002. State-Building: Governance and World Order in the 21st Century. New York: Cornell University Press.

Gadzhiev, Kamaludin. 2012. The Principles of Self-Organization of the Polycentric World Order. Power 6: 162-66.

Galchynskyi, Anatoliy. 2011. Beyond Capitalism. Economy of Ukraine 9: 4-16.

Galiani, Sebastian, Ivan Torre, and Gustavo Torrens. 2019. International organizations and the political economy of reforms. Journal of International Economics 121: 103249. [CrossRef]

Garrett, R. Kelly. 2006. Protest in an Information Society: A review of literature on social movements and new ICTs. Information, Communication \& Society 9: 202-24. [CrossRef]

Geels, Frank. 2005. Co-evolution of technology and society: The transition in water supply and personal hygiene in the Netherlands (1850-1930)_A case study in multi-level perspective. Technology in Society 27: 363-97. [CrossRef]

Gilpin, Robert. 1987. The Political Economy of International Relations. Princeton: Princeton University Press.

Golovakha, Evheniy, and Nataliia Panina. 2001. Post-Soviet Deinstitutionalization and the Formation of New Social Institutions in Ukrainian Society. Sociology: Theory, Methods, and Marketing 4: 5-22.

Graham, Benjamin A. T., and Jacob R. Tucker. 2019. The international political economy data resource. The Review of International Organizations 14: 149-61. [CrossRef]

Graz, Jean-Christophe, Oliver Kessler, and Rahel Kunz. 2020. International Political Economy (IPE) meets International Political Sociology (IPS). International Relations 33: 586-94. [CrossRef]

Hegel, Georg Wilhelm Friedrich. 2018. The Phenomenology of Spirit. Oxford: Oxford University Press.

Hrytsenko, Andrii. 2015. Methodology of Research of Institutional Transformations under Conditions of the Combination of Inversion Type of Market Transformations and Globalization of the Economy. In Institutional Transformations of the Socio-Economic System of Ukraine: Monograph. Edited by Andrii Hrytsenko. Kyiv: The Institute for Economics and Forecasting of the National Academy of Sciences of Ukraine, pp. 9-29.

Hrytsenko, Andrii. 2018. Digital Development: Structure, Capitalization and Socialization. Economic Theory 4: 5-20. [CrossRef]

Huang, Yongfu. 2010. Political Institutions and Financial Development: An Empirical Study. World Development 38: 1667-77. [CrossRef]

Huntington, Samuel P. 1993. The Clash of Civilizations? Foreign Affairs 72: 22-49. [CrossRef]

Hussain, Hafezali Iqbal, Beata Slusarczyk, Fakarudin Kamarudin, Hassanudin M. T. Thaker, and Katarzyna Szczepańska-Woszczyna. 2020. An Investigation of an Adaptive Neuro-Fuzzy Inference System to Predict the Relationship among Energy Intensity, Globalization, and Financial Development in Major ASEAN Economies. Energies 13: 850. [CrossRef]

Hussain, Hafezali Iqbal, Katarzyna Szczepańska-Woszczyna, Fakarudin Kamarudin, Nazratul Aina Mohamad Anwar, and Mohd Haizam Mohd Saudi. 2021. Unboxing the Black Box on the Dimensions of Social Globalisation and the Efficiency of Microfinance Institutions in Asia. Oeconomia Copernicana 12: 557-92. [CrossRef]

Keohane, Robert O., and Joseph S. Nye. 1977. Power and Interdependence: World Politics in Transition. Boston: Little Brown \& Co.

Kharazishvili, Yrii, Aleksy Kwilinski, Olena Grishnova, and Henryk Dzwigol. 2020. Social Safety of Society for Developing Countries to Meet Sustainable Development Standards: Indicators, Level, Strategic Benchmarks (with Calculations Based on the Case Study of Ukraine). Sustainability 12: 8953. [CrossRef]

Kharazishvili, Yrii, Aleksy Kwilinski, Oleksandr Sukhodolia, Henryk Dzwigol, Dmytro Bobro, and Janusz Kotowicz. 2021a. The Systemic Approach for Estimating and Strategizing Energy Security: The Case of Ukraine. Energies 14: 2126. [CrossRef]

Kharazishvili, Yrii, Aleksy Kwilinski, Henryk Dzwigol, and Viacheslav Liashenko. 2021b. Strategic European Integration Scenarios of Ukrainian and Polish Research, Education and Innovation Spaces. Virtual Economics 4: 7-40. [CrossRef] 
Kravchenko, Sergey. 2019. Simulation of the national innovation systems development: A transnational and coevolution approach. Virtual Economics 2: 41-54. [CrossRef]

Kurowska-Pysz, Joanna, and Katarzyna Szczepańska-Woszczyna. 2017. The Analysis of the Determinants of Sustainable Cross-Border Cooperation and Recommendations on Its Harmonization. Sustainability 9: 2226. [CrossRef]

Kuzior, Aleksandra, Anna Liakisheva, Iryna Denysiuk, Halyna Oliinyk, and Liudmyla Honchar. 2020. Social Risks of International Labour Migration in the Context of Global Challenges. Journal of Risk and Financial Management 13: 197. [CrossRef]

Kwilinski, Aleksy, Nataliya Dalevska, Sergey Kravchenko, Ihor Hroznyi, and Olena Kovalenko. 2019. Formation of the entrepreneurship model of e-business in the context of the introduction of information and communication technologies. Journal of Entrepreneurship Education 22: 1-7.

Kwilinski, Aleksy, Oleksandr Vyshnevskyi, and Henryk Dzwigol. 2020. Digitalization of the EU Economies and People at Risk of Poverty or Social Exclusion. Journal of Risk and Financial Management 13: 142. [CrossRef]

Las Heras, Jon. 2018. International Political Economy of Labour and collective bargaining in the automotive industry. Competition $\mathcal{E}$ Change 22: 313-31. [CrossRef]

Laszlo, Ervin. 1991. The Age of Bifurcation: Understanding the Changing World. Philadelphia: Gordon \& Breach Science Publishers, vol. 3.

Laszlo, Alexander, and Stanley Krippner. 1998. Systems Theories: Their Origins, Foundations, and Development. In Systems Theories and A Priori Aspects of Perception. Edited by J. Scott Jordan. Amsterdam: Elsevier Science, chp. 3. pp. 47-74.

Levitt, Theodore. 1983. The Globalization of Markets. Harvard Business Review, May-June. 2-11.

Marlin-Bennett, Renée, and David K. Johnson. 2021. International Political Economy: Overview and Conceptualization. Oxford Research Encyclopedia of International Studies. Available online: https:/ / doi.org/10.1093/acrefore/9780190846626.013.239 (accessed on 3 February 2022).

Masuda, Yoneji. 1983. The Information Society as Postindustrial Society. Washington: World Future Society.

McNally, Christopher A. 2012. Sino-Capitalism: China's reemergence and the international political economy. World Politics 64: 741-76. [CrossRef]

Medeiros, Eduardo. 2021. The Global Development Formula. Sustainability 13: 5262. [CrossRef]

Morgenthau, Hans. 1948. Politics among Nations: The Struggle for Power and Peace. New York: Alfred A. Knopf.

Nunn, Alex, and Stuart Shields. 2022. The Intellectual and Institutional Challenges for International Political Economy in the UK: Findings from Practitioner Survey Data. Review of International Studies 2022: 1-20. [CrossRef]

Parsons, Talcott. 1971. The System of Modern Societies. Englewood Cliffs: Prentice-Hall.

Paterson, Matthew. 2021. Climate change and international political economy: Between collapse and transformation. Review of International Political Economy 28: 394-405. [CrossRef]

Porter, Michael E. 1998. Clusters and the new economics of competition. Harvard Business Review 76: 78-90.

Postlewaite, Andrew, and David Schmeidler. 1986. Implementation in differential information economies. Journal of Economic Theory 39: 14-33. [CrossRef]

Ringquist, Evan J. 2003. Environmental Justice: Normative Concerns Empirical Evidence, and Governmental Action. In Environmental Policy, 5th ed. Edited by Norman J. Vig and Michael E. Kraft. Washington: Congressional Quarterly, pp. 249-74.

Robertson, Roland. 1992. Globalization: Social Theory and Global Culture. London: Sage Publications.

Rosenau, James N. 2006. The Study of World Politics. Volume 1: Theoretical and Methodological Challenges. London and New York: Routledge.

Ruggie, John Gerard. 1982. International Regimes, Transactions, and Change: Embedded Liberalism in the Postwar Economic System. International Organization 36: 379-415. [CrossRef]

Sabadash, Viktor, and Pavlo Denysenko. 2018. Economic and social dimensions of ecological conflicts: Root causes, risks, prevention and mitigation measures. International Journal of Environmental Technology and Management 21: 273-88. [CrossRef]

Savchuk, Volodymyr S. 2011. International or Global Political Economy. In Methodological Problems of Modern Political Economy. Edited by Oleksandr Belyaev. Kyiv: Kyiv National University of Economics named after V. Hetman, pp. 175-85.

Shkodina, Iryna, Oleksandr Melnychenko, and Maksym Babenko. 2020. Quantitative Easing Policy and Its Impact on the Global Economy. Financial and Credit Activity: Problems of Theory and Practice 2: 513-21. [CrossRef]

Simmons, Beth A., and Elkins Zachary. 2004. The Globalization of Liberalization: Policy Diffusion in the International Political Economy. American Political Science Review 98: 171-89. [CrossRef]

Smirnova, Elena, Katarzyna Szczepańska-Woszczyna, Saltanat Yessetova, Vadim Samusenkov, and Rodion Rogulin. 2021. Supplying Energy to Vulnerable Segments of the Population: Macro-Financial Risks and Public Welfare. Energies 14: 1834. [CrossRef]

Smith, David A., and Douglas R. White. 1992. Structure and Dynamics of the Global Economy: Network Analysis of International Trade 1965-1980. Social Forces 70: 857-93. [CrossRef]

Stiglitz, Joseph E. 2002. Globalization and Its Discontents. New York and London: W.W. Norton \& Company.

Strange, Susan. 1988. States and Markets. London: Pinter Publishers.

Tanaka, Kiyoyasu. 2021. The European Union's reform in rules of origin and international trade: Evidence from Cambodia. The World Economy 44: 3025-50. [CrossRef]

Tarasevych, Viktor M. 2012. Political Economy: Name Proper, Broad Meaning and Subject Space. Economic Theory 1: 21-34.

Toffler, Alvin. 1980. The Third Wave. New York: Bantam Books. 
Tsoukas, Haridimos. 1997. The tyranny of light: The temptations and the paradoxes of the information society. Futures $29: 827-43$. [CrossRef]

van Ommeren, Emile, Arlo Poletti, and Dirk De Bièvre. 2021. The European Union and the political economy of enforcing international trade rules. European Union Politics 22: 377-400. [CrossRef]

Wallerstein, Immanuel Maurice. 1995. After Liberalism. New York: New Press.

Wallerstein, Immanuel Maurice, and Armand Clesse. 2003. The World We Are Entering 2000-2050. Amsterdam: Dutch University Press.

White, Melissa Autumn. 2015. Virus. In Making Things International 1: Circuits and Motion. Edited by Mark B. Salter. Minneapolis: University of Minnesota Press, pp. 141-155. 